\title{
CHANGES IN THE SYNTHESIS OF EXPORTABLE AND NONEXPORTABLE PROTEINS IN PAROTID GLANDS DURING AGING
}

\author{
SUN-KEE KIM ${ }^{1}$, DEBBY W. CALKINS ${ }^{2}$, PAUL A. WEINHOLD ${ }^{3}$ and SEONG S. HAN ${ }^{4}$ \\ Research Service, V.A. Medical Center ${ }^{1,3}$, Ann Arbor, Michigan 48105 (U.S.A.), and Departments of \\ Anatomy $y^{1,2,4}$ and Biochemistry ${ }^{3}$, The University of Michigan Medical School, Ann Arbor, Michigan \\ (U.S.A.)
}

(Received September 3, 1981; in revised form December 1, 1981)

\section{SUMMARY}

The age-related differences in the synthesis of exportable and nonexportable proteins of the parotid salivary gland were compared in 2- and 24-month-old rats. Parotid slices from these rats were incubated in the presence of $\left[{ }^{14} \mathrm{C}\right]$ leucine and the amount of radioactivity incorporated into the water-soluble proteins of the postmicrosomal supernatant was compared. The exportable and nonexportable proteins were identified by electrophoretic separation of these proteins by comparing the banding patterns of the gel preparations from unstimulated glands to those from the glands stimulated to secrete. The radioactivity determination in various protein bands from these rats indicated that the synthesis of exportable secretory proteins declined with age, while that of nonexportable proteins did not appear to change.

\section{INTRODUCTION}

Many organs, including the digestive glands, undergo a process of involution with advancing age, which leads to a reduction in organ function. In salivary glands, reductions occur in the amylase content in saliva [1-3] as well as the secretion and rate of flow of saliva $[4,5]$. The reduced amylase content and secretion of saliva suggest that the cellular level of secretory proteins is reduced, possibly due to the decline in the synthesis of these proteins. In fact, our previous studies have shown that the rate of protein synthesis declines progressively with age in rat parotid glands [6-8]. In parotid glands of the rat, the rate of protein synthesis declines progressively between the ages of 2 and 30 months, as indicated by the reduction in the rate of incorporation of labelled amino acids into the acid-insoluble proteins of this gland $[6,7]$. These findings are consistent with the results of many previous studies, which have reported the age-related decline in protein synthesis in different types of organs and tissues, such as brain [9-13], muscle [14-16], testis [17], liver [18-29] and heart [28]. 
However, it does not appear that all cellular proteins are uniformly affected during aging. As demonstrated in the livers of rats [28, 30,31] and mice [28], the synthesis of albumin increases with age, and the synthesis of ferritin does not change [30], while that of heme protein declines [28]. These results suggest that the synthesis of proteins with different functions is affected during aging, depending on the cellular needs for these proteins, and that the age-related changes in some proteins can be masked if only the synthesis of total proteins is investigated [30].

In this study, we have compared the age-related differences in the synthesis of exportable, secretory proteins in rat parotid glands and examined whether there are differences in the way the synthesis of these proteins and nonexportable proteins is affected with age. The parotid gland of the rat provides an excellent system for this type of study. In this gland, $50 \%$ of all the protein is exportable [32] and nearly all the exportable proteins can be induced to secrete $[33,34]$. Also, the gland secretes totally serous products, consisting primarily of $\alpha$-amylase [34], which can be assayed readily.

The $\alpha$-amylase and other secretory proteins have been separated by electrophoresis of water-soluble, postmicrosomal supernatant (PMS) of the rat parotid gland. These proteins have been identified by comparing the gel preparations of the unstimulated glands with those of the glands stimulated to secrete nearly all the stored secretory products. Comparisons of the radioactive amino acid incorporation into the proteins of the various bands have indicated that the synthesis of secretory proteins declines, while that of the nonexportable protein does not change with age.

\section{MATERIALS AND METHODS}

\section{Animals}

Male Sprague-Dawley rats, obtained from Charles River Breeding Laboratories in Portage, Michigan, were used for this study. The young rats were about 2 months' old and weighed between 200 and 250 grams. The old rats were $23-25$ months' old and came from the aging colony at the Portage facility. These rats weighed 550-650 grams. All animals were Caesarean-derived and maintained behind a barrier containment facility. They were monitored regularly by serological means for mucoplasmosis, pathogenic organisms, parasites and for sialodacryoadenitis (SDA) viruses which affect the structure and function of salivary glands. Rats used in this study showed negative titers for the SDA viruses which are widespread in other commercially available rats. Food was withheld about 16 hours before experiments were initiated. Rats were killed between 8 and 9 a.m. by cervical dislocation.

\section{Labelling with $/ \mathrm{U}_{-}^{14} \mathrm{C} /$ leucine}

The detailed procedures for incubation with the radioactive amino acid have been described previously [6-8]. In this study, parotid slices, cleaned of connective tissue and fat, were incubated in Minimum Essential Medium (MEM) without leucine supplemented with $\left[\mathrm{U}^{14} \mathrm{C}\right]$ leucine $(9 \mu \mathrm{Ci} / \mathrm{ml}$; specific activity $351 \mathrm{mCi} / \mathrm{mmol}$; Amersham). Slices were 
incubated for 60 minutes at $37{ }^{\circ} \mathrm{C}$ with constant agitation ( $\left.80 \mathrm{cycles} / \mathrm{min}\right)$ and continuous gassing $\left(95 \% \mathrm{O}_{2}\right.$ and $\left.5 \% \mathrm{CO}_{2}\right)$.

After incubation, tissues were filtered through miracloth, rinsed with phosphatebuffered saline (PBS) and homogenized. Homogenizations were done in PBS containing $0.3 \mathrm{M}$ sucrose $(10: 1, \mathrm{v} / \mathrm{w})$ using Potter--Elvehjem-type vessels with Teflon pestles. Insufficiently homogenized tissues were removed by centrifuging at $150 \mathrm{~g}$ for 10 minutes, and the postmicrosomal supernatant (PMS) was obtained through a series of centrifugations according to the method of Amsterdam et al. [35].

\section{Gel electrophoresis}

Sodium dodecyl sulfate (SDS) gel electrophoresis was performed by the procedure modified from that described by Keleti and Lederer [36]. After the determination of the protein content, as described by Lowry et al. [37], samples were diluted with 0.01 $\mathrm{M}$ sodium phosphate buffer containing $1 \%$ SDS and $1 \% \beta$-mercaptoethanol. The samples were incubated overnight at $37{ }^{\circ} \mathrm{C}$ and were diluted again with the same buffer. After adding $5 \mu \mathrm{l}$ each of bromophenol blue and $\beta$-mercaptoethanol to the samples, $30 \mu \mathrm{g}$ or $72 \mu \mathrm{g}$ of protein were loaded onto the surface of $10 \%$ polacrylamide gel. The electrophoresis was carried out for 6.5 hours at $7 \mathrm{~mA} /$ tube in a 12-place vertical gel column cell using $0.1 \mathrm{M}$ sodium phosphate buffer containing $1 \%$ SDS as an electrode buffer. Following this, the gels were stained with $0.25 \%$ Coomassie Brilliant Blue $\mathrm{R}$ for 8 hours and destained in a solution containing $20 \%$ ethanol and $7 \%$ glacial acetic acid for 36 hours. The destaining solution was changed every 8 hours.

\section{Radioactivity determinations}

After gels had been stained and destained, they were scanned on a Beckman spectrophotometer modified with a Gilford linear transport system. The scan speed was $1 \mathrm{~cm} /$ min with a chart speed of $2 \mathrm{~cm} / \mathrm{min}$. These gels were then frozen on dry ice and serially sliced into $0.5-\mathrm{mm}$ sections on a Mickle gel slicer.

For quantification of protein in each band, the dye elution method of Fenner et al. [38] was used. Frozen slices from each gel were reconstructed by placing the sections side by side in a Petri dish wetted with destaining solution. When the gel had thawed, the slices making up the bands were plucked from the gel and placed in a PotterElvehjem homogenizer for homogenization in $25 \%$ pyridine in water (v/v). Following homogenization, the gel-pyridine mixture was placed in a capped, graduated, conical centrifuge tube and shaken overnight at room temperature. The next morning, the tubes were centrifuged $(2300 \mathrm{~g})$ for 10 minutes in a Sorvall RC-3 centrifuge. The absorbance $(605 \mathrm{~nm})$ of a $1-\mathrm{ml}$ volume of each supernatant containing the eluted dye was determined. Total absorbance for a sample was calculated as $A_{605} / \mathrm{ml} \times \mathrm{ml} / \mathrm{sample}$. The $1-\mathrm{ml}$ aliquot of supernatant used for absorbance measurement was pipetted back into its respective tube which was then vortexed vigorously. Aliquots of $0.2 \mathrm{ml}$ were withdrawn for a 2-hour digestion at $50^{\circ} \mathrm{C}$ in $0.5 \mathrm{ml}$ of a water-NCS (Amersham) mixture. Vials were cooled to room temperature before adding $10 \mathrm{ml}$ of OCS (Amersham) for scintillation counting. Radioactivity in each band of the two age groups was counted in a Beckman 
LS 9000 liquid scintillation spectrophotometer and compared based on dpm/ $A_{605}$ unit. The ratios of radioactivity incorporation into various protein bands at 2 and 24 months in each experiment were compared separately to minimize variations related to the differences in the staining and amount of radioactivity used during incubation.

\section{Isoproterenol-stimulated secretion}

To identify exportable and nonexportable proteins, parotid glands were stimulated to secrete by an injection of isoproterenol (IPR) or by incubating the glandular lobules with the secretogogue. A single intraperitoneal injection of IPR (Sigma, $0.8 \mathrm{mg}$ per $100 \mathrm{~g}$ body weight) induces a near complete discharge of the stored secretory product within 1 hour as evidenced by about $98 \%$ reduction in the glandular tissue $\alpha$-amylase activity $[33,34]$. To obtain the PMS fractions from stimulated glands, rats were killed 1 hour after the injection of IPR and the glands were removed. These glands were minced, homogenized and the PMS was obtained as described above. The $\alpha$-amylase activity and the protein content in the homogenate were assayed by the Amylochome method [34], and by the method of Lowry et al. [37], respectively. SDS-gel electrophoresis was performed with the PMS as described above.

\section{In vitro IPR stimulation of parotid lobules}

Upon removal from the rat, parotid glands were immersed in MEM warmed to $37{ }^{\circ} \mathrm{C}$ and gassed with $95 \% \mathrm{O}_{2}+5 \% \mathrm{CO}_{2}$. Glands were cleaned of connective tissue, nerves, large ducts, blood vessels and fat under a dissecting microscope. Parotid lobules were isolated manually with Dumont No. 5 forceps with fine tips. (MEM was continuously gassed with $95 \% \mathrm{O}_{2}+5 \% \mathrm{CO}_{2}$ throughout the isolation.) Following a 15 -minute preincubation in MEM at $37{ }^{\circ} \mathrm{C}$, lobules were transferred to MEM containing distilled water (control) and IPR at a concentration of $10^{-5} \mathrm{M}$. Lobules were incubated at $37^{\circ} \mathrm{C}$ in this medium for 2 hours, with a booster shot of fresh IPR added every 30 minutes to replace oxidized and used IPR [39]. After this incubation, the medium was collected and saved. Following homogenization of lobules, an aliquot of homogenate and medium was set aside for $\alpha$-amylase assay. Following a 10 -minute centrifugation at $150 \mathrm{~g}$, the PMS was obtained from the supernatant. Aliquots of medium and PMS were dialyzed for 72 hours against PBS. After the protein content determinations, SDS-gel electrophoresis was performed with the PMS or medium (dialyzed and undialyzed).

\section{RESULTS}

The postmicrosomal water-soluble proteins of the gland separate into numerous bands upon electrophoresis on SDS-polyacrylamide gels and staining with Coomassie Brilliant Blue R (Fig. 1). Many of these bands are distinct, although there are some bands which stain faintly and their boundaries are not clearly defined. The incubation of the gland slices in the presence of $\left[{ }^{14} \mathrm{C}\right]$ leucine does not significantly alter the banding pattern (Fig. $1 Y$ and $\mathrm{O}$ ) with the exception of the disappearance of a band indicated by the 


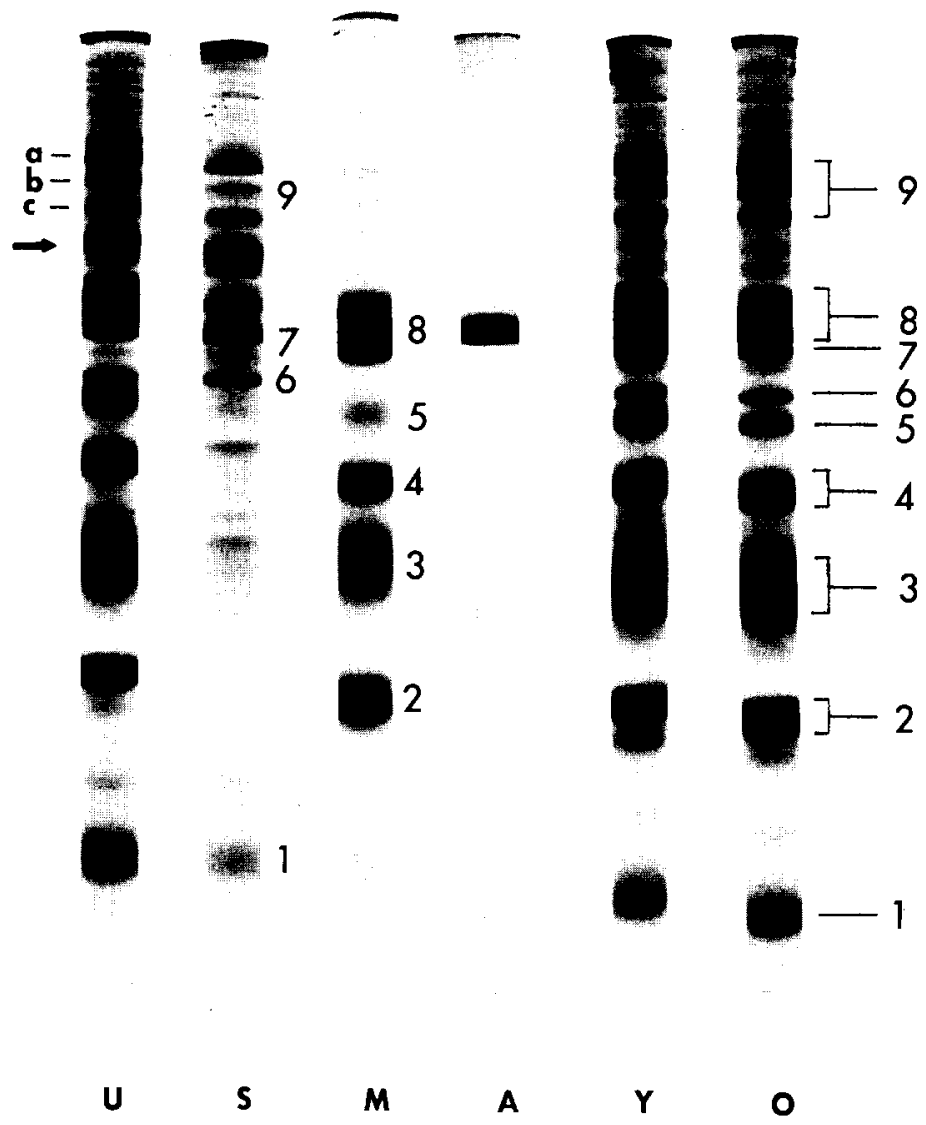

Fig. 1. SDS-polyacrylamide gel electrophoresis of the parotid gland proteins. (U) the PMS of the unstimulated glands; (S) the PMS of the glands stimulated to secrete by an injection of IPR; (M) the medium in which parotid lobules were incubated in the presence of IPR; (A) $\alpha$-amylase from porcine pancreas (commercially obtained); (Y) the PMS of the glands from 2-month-old rats; $(0)$ the PMS of the glands from 24 month-old-rats. The glands used for $\mathrm{Y}$ and $\mathrm{O}$ had been incubated with $\left[{ }^{14} \mathrm{Cl}\right.$ ]leucine. The incubation does not affect the banding pattern, with the exception of the disappearance of a band (indicated by arrow in U). The bands are numbered 1-9 for the purpose of identification in this study. The bands $2,3,4,5$, and 8 ( $\alpha$-amylase) correspond to exportable secretory proteins. The bands labelled $a, b$, and $c$ in $U$ were combined for the purpose of radioactivity determination.

arrow in Fig. 1U. Also, the banding patterns of the gel preparations from 2- and 24 month-old rats are nearly identical except for slight differences in staining intensity in a few bands (Fig. 1Y and 0 ). For the purpose of radioactivity determinations in this study, the bands are numbered 1-9. The bands, labelled as a, b and $\mathrm{c}$ in Fig. 1U, are combined as these bands seem to be composed of nonexportable proteins and each band incorporates only a small amount of radioactivity.

The exportable and nonexportable proteins of the gland have been identified by comparing the banding patterns from unstimulated glands with those prepared with the glands stimulated to secrete either by injecting or incubating with IPR. In gels prepared with the PMS from the glands 1 hour after the IPR-stimulated secretion, bands 2, 3, 4, 5, 
and 8 are either absent or greatly reduced in width (Fig. 1S). On the other hand, these bands are very distinct in gels prepared with the MEM in which parotid lobules were incubated in the presence of $10^{-5} \mathrm{M}$ IPR (Fig. 1M). The incubation of the parotid lobules with this concentration of IPR results in a $65 \%$ release of amylase from the tissue. As can be seen in Fig. 1M, proteins present in bands 2, 3,4,5, and 8 are highly concentrated in the medium after 2 hours of incubation. Furthermore, the protein band 8 has been identified as $\alpha$-amylase as it comigrates with the enzyme purified from porcine pancreas, obtained from Sigma (Fig. 1A). The proteins of the bands 1,6, 7, and 9 are either present in minute quantities in the medium or are not detectable by SDS-gel electrophoresis.

Following a 1 -hour incubation of the gland slices in the presence of $\left[{ }^{14} \mathrm{C}\right]$ leucine, the specific radioactivity in the PMS of the gland from young rats is significantly higher than that of the older group (Table I). The radioactivity determination of the serial sections throughout the length of the gel has shown that the incorporation of $\left[{ }^{14} \mathrm{C}\right]$ leucine occurs into proteins in various bands. In both age groups (Fig. 2A and B), the radioactivity peaks generally coincide with peaks of staining intensity obtained by spectrophotometric scans of the stained gels.

The radioactivity incorporation in various protein bands in 2- and 24-month-old rats can be compared based on the units of absorption of the dye in each band, as there is a direct correlation between the absorption of dye units and the amount of protein loaded on the gel up to $72 \mu \mathrm{g}$ of protein (Fig. 3). The proportions of staining intensity and radioactivity associated with each band are similar in the two age groups (Table II). In both groups, the highest staining intensity is associated with $a$-amylase, band 8 . The highest level of radioactivity is found in band 2 in both groups. The level of radioactivity in bands $2,3,4,5$, and 8 is significantly lower in the older group compared with that in the younger rats (Table III). The mean ratio for the radioactivity incorporation into the bands of secretory proteins is 0.76 ( 24 months $/ 2$ months). On the other hand, the same ratio for bands $1,6,7$, and 9 is 0.99 . The difference in these ratios for the two groups of proteins is significant $(0.01<p<0.02)$.

\section{DISCUSSION}

The water-soluble proteins of the PMS from the parotid gland of 2- and 24-monthold rats are similar in their electrophoretic mobility and form nearly identical banding

\section{TABLE I}

SPECIFIC RADIOACTIVITY IN THE PMS OF THE PAROTID GLAND FOLLOWING 1 HOUR INCUBATION WITH $\left[{ }^{14} \mathrm{C}\right]$ LEUCINE

\begin{tabular}{|c|c|c|}
\hline Age (months) & No. samples & $\mathrm{dpm} / \mathrm{mg}$ protein $\pm S . E .\left(\times 10^{4}\right)$ \\
\hline 2 & 6 & $2.13 \pm 0.12$ \\
\hline 24 & 6 & $1.64 \pm 0.11$ \\
\hline
\end{tabular}



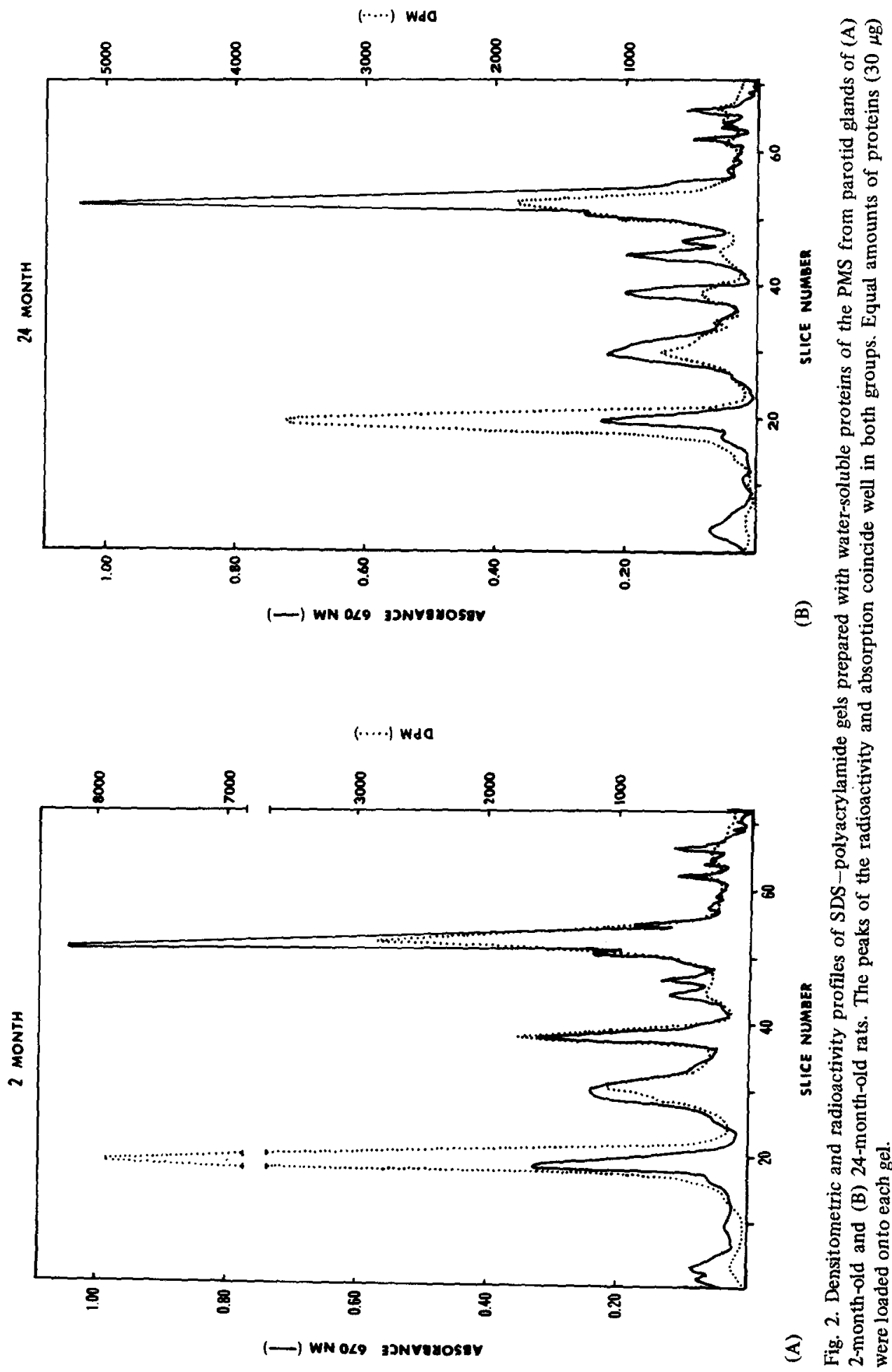


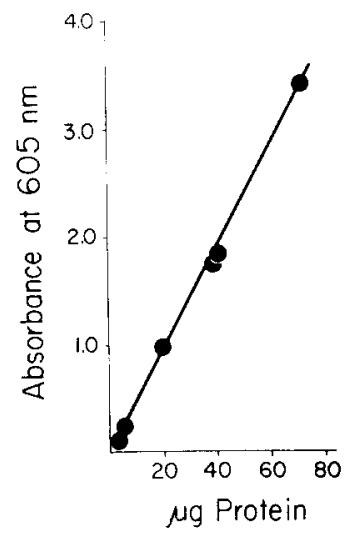

Fig. 3. The relationship between protein concentration and dye binding. Gels were prepared with varying amounts of $\alpha$-amylase (obtained from Sigma) and stained with Coomassie Blue. The dye was eluted with $25 \%$ pyridine in water and the absorbance was measured. There is a linear relationship between the protein concentration and absorbance up to $75 \mu \mathrm{g}$.

TABLE II

COMPARISONS OF STAINING INTENSITY AND RADIOACTIVITY IN PROTEIN BANDS OF THE PMS FROM PAROTID GLANDS OF YOUNG AND OLD RATS

\begin{tabular}{|c|c|c|c|c|}
\hline \multirow[t]{2}{*}{ Band $^{*}$} & \multicolumn{2}{|c|}{$\begin{array}{l}2 \text { months } \\
\text { Percentage of total }\end{array}$} & \multicolumn{2}{|c|}{$\begin{array}{l}24 \text { months } \\
\text { Percentage of total }\end{array}$} \\
\hline & Absorbance & Radioactivity & Absorbance & Radioactivity \\
\hline $1(\mathrm{NE})$ & $3.74 \pm 0.53$ & $2.92 \pm 0.31$ & $3.62 \pm 0.39$ & $2.61 \pm 0.29$ \\
\hline $2(\mathrm{EX})$ & $12.54 \pm 0.32$ & $51.29 \pm 2.46$ & $13.38 \pm 1.59$ & $45.34 \pm 2.78$ \\
\hline $3(\mathrm{EX})$ & $15.99 \pm 1.68$ & $8.24 \pm 0.79$ & $14.39 \pm 1.93$ & $7.83 \pm 0.55$ \\
\hline $4(\mathrm{EX})$ & $9.04 \pm 1.53$ & $10.47 \pm 0.80$ & $8.88 \pm 1.58$ & $9.22 \pm 0.72$ \\
\hline $5(\mathrm{EX})$ & $4.78 \pm 0.56$ & $6.79 \pm 0.75$ & $3.03 \pm 0.45$ & $5.21 \pm 0.71$ \\
\hline $6(\mathrm{NE})$ & $3.16 \pm 0.53$ & $4.19 \pm 0.65$ & $2.56 \pm 0.59$ & $5.21 \pm 0.54$ \\
\hline $7(\mathrm{NE})$ & $3.17 \pm 0.29$ & $6.17 \pm 1.08$ & $3.22 \pm 0.21$ & $6.33 \pm 0.73$ \\
\hline $8(\mathrm{EX})$ & $42.07 \pm 1.69$ & $12.09 \pm 0.86$ & $48.78 \pm 2.57$ & $11.54 \pm 0.51$ \\
\hline $9(\mathrm{NE})$ & $7.49 \pm 0.26$ & $6.83 \pm 0.85$ & $7.06 \pm 1.36$ & $6.69 \pm 0.47$ \\
\hline NE & 17.56 & 20.11 & 16.46 & 20.84 \\
\hline $\mathrm{EX}$ & 82.44 & 79.89 & 83.54 & 79.16 \\
\hline
\end{tabular}

${ }^{*} \mathrm{NE}=$ nonexportable, $\mathrm{EX}=$ exportable.

patterns in SDS-polyacrylamide gel preparations. Also, the distributions of proteins in various bands are similar, as measured by the staining intensity, as are the proportions of radioactivity incorporated into the bands in these two age groups.

However, the rate of synthesis of proteins appears to decline with age as evidenced by the lower level of radioactivity in the PMS of the parotid glands from 24-month-old rats compared with that from 2-month-old rats following 1 hour incubation with $\left[{ }^{14} \mathrm{C}\right]$ leucine. These results confirm those from our previous studies based on the incorporation of leucine into the acid-insoluble protein of the gland $[6-8]$. The reduced level 
TABLE III

COMPARISON OF $\left[{ }^{14} \mathrm{C}\right]$ LEUCINE INCORPORATION INTO PROTEIN BANDS OF THE PAROTID GLAND IN YOUNG AND OLD RATS

\begin{tabular}{lc}
\hline Band & Ratio $\frac{d p m / A_{605}(24 \text { months })}{d p m / A_{605}(2 \text { months })} \pm S . E$. \\
\hline $1 \mathrm{NE}$ & $0.880 \pm 0.105$ \\
$2 \mathrm{EX}$ & $0.761 \pm 0.063$ \\
$3 \mathrm{EX}$ & $0.818 \pm 0.037$ \\
$4 \mathrm{EX}$ & $0.758 \pm 0.002$ \\
$5 \mathrm{EX}$ & $0.661 \pm 0.167$ \\
$6 \mathrm{NE}$ & $1.115 \pm 0.060$ \\
$7 \mathrm{NE}$ & $0.958 \pm 0.054$ \\
$8 \mathrm{EX}$ & $0.811 \pm 0.026$ \\
$9 \mathrm{NE}$ & $0.880 \pm 0.079$ \\
Mean ratio for $\mathrm{NE}(n=30): 0.980 \pm 0.071$ \\
\end{tabular}

*NE $=$ nonexportable, $\mathrm{EX}=$ exportable.

of incorporation of $\left[{ }^{14} \mathrm{C}\right]$ leucine appears to reflect the reduction in the synthesis of secretory proteins; the radioactivity in all bands corresponding to exportable proteins is reduced in the older group by about $24 \%$ of the level in the younger group (Table III). This level of reduction correlates closely with the difference of about $23 \%$ in the specific radioactivity in the PMS of the gland at 2 and 24 months (Table I). On the other hand, the level of incorporation of the amino acid into nonexportable proteins is not different at these two ages.

The reduced level of $\left[{ }^{14} \mathrm{C}\right]$ leucine incorporation does not appear to be due to the age-related differences in the size of the amino acid pool or the precursor specific radioactivity. Our preliminary results of the amino acid analysis of the acid-soluble pool have indicated that there is no significant difference in the size of the leucine pool at 2 and 24 months, and that the specific radioactivity of the pool is somewhat higher at 24 months

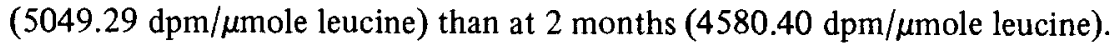

Despite the decline in the synthesis of exportable proteins, there is no significant difference in the cellular level of secretory proteins as evidenced by the similar level of cellular $\alpha$-amylase in glands of 2- and 24-month-old rats [40]. These results suggest that the secretory activity of the gland is reduced in the older rats and that the secretory proteins are stored for a longer period of time in these rats than in the younger ones, presumably due to the decreased level of digestive activity. Apparently, the ability of the parotid gland cells to release secretory proteins does not change with age $[40,41]$.

Previous studies have shown that the synthetic and secretory activities in exocrine glands are interrelated $[34,42-45]$, and it is possible that the decline in secretory protein synthesis in rat parotid glands is related to the reduced level of secretory activity. It does not seem likely that the release of stored secretory products itself has stimulatory 
effects on the synthesis of more proteins. However, the reduced level of intracellular secretory proteins might induce a compensatory burst of synthetic activity [34]. In rat parotid glands [34], the incorporation of labelled amino acids into total protein and amylase increases greatly (about 6.5-fold) following the stimulated secretion of nearly all the stored secretory proteins by an injection of IPR.

On the other hand, many previous studies in widely different types of organs and tissues have indicated that the age-related decline in protein synthesis is related to various changes which affect the process of transcription and translation of the genetic code. Many recent studies have indicated that the reduced protein synthesis in animal cells with age is caused by changes in the microsomes or ribosomes. It has been shown in a cell-free system that microsomes isolated from various tissues of old animals are less able to incorporate amino acids into acid-insoluble proteins than the microsomes from younger animals $[9-15,17,18,21,23,25-28]$. More specifically, the reduced level of incorporation has been attributed to various factors including reductions in the concentration of polysomes $[15,27]$, active ribosomes [26], defects in one of the subunits of the ribosomes [23], reduced ribosome aggregation to mRNA [27], or mRNA complexing ability [25]. These results indicated that quantitative and/or qualitative changes may occur in mRNA and/or ribosomes during aging. In rat parotid glands [39], as in the pancreas [46], the protein destined to be packaged into secretory granules appears to be synthesized by those ribosomes that are associated with the membranes of the endoplasmic reticulum. The membrane-bound ribosomes apparently synthesize other secretory proteins such as serum albumin $[47,48]$, immunoglobulin [49] and casein [50]. However, it is unknown whether the age-related reductions in the synthesis of secretory proteins in parotid glands of the rat are accompanied by any changes in membrane-bound ribosomes.

\section{REFERENCES}

1 J. Meyer and H. Necheles, Studies in old age. IV. The clinical significance of salivary, gastric and pancreatic secretion in the aged. J. Am. Med. Assoc., 155 (1940) 2050-2053.

2 J. Meyer, J. S. Golden, N. Steiner and H. Necheles, The ptyalin content of human saliva in old age. Am. J. Physiol., 119 (1937) 600-602.

3 R. Chilla, H. Niemann, C. Arglebe and G. F. Domagk, Age-dependent changes in the alpha-isoamylase pattern of human and rat parotid glands. ORL-J. Oto-Rhino-Laryngol. Its Borderl., 36 (1974) $372-382$.

4 H. Necheles, F. Plotke and J. Meyer, Studies on old age. V. Active pancreatic secretion in the aged. Am. J. Dig. Dis., 9 (1942) 157-159.

5 U. Bertram, Xerostomia: Clinical aspects, pathology and pathogenesis. Acta Odontol. Scand., 25 (Suppl. 49) (1967) 1-126.

6 S. K. Kim, P. A. Weinhold, S. S. Han and D. J. Wagner, Age-related decline in protein synthesis in the rat parotid gland. Exp. Gerontol., 15 (1980) 77-85.

7 S. K. Kim, Age-related changes in the cellular level of amylase and protein synthesis in the rat parotid gland. J. Dent. Res., 60 (1981) 738-747.

8 S. K. Kim, P. A. Weinhold, D. W. Calkins and V. W. Hartog, Comparative studies of the age-related changes in protein synthesis in the rat pancreas and parotid gland. Exp. Gerontol, 16 (1981) 91-99. 
9 M. R. V. Murthy and D. A. Rappoport, Biochemistry of the developing rat brain: V. Cell-free incorporation of L- $\left[1-{ }^{14} \mathrm{C}\right]$ leucine into microsomal protein. Biochim. Biophys. Acta, 95 (1965) 121-131.

10 M. R. V. Murthy, Protein synthesis in growing rat tissues: II. Polyribosome concentration of brain and liver as a function of age. Biochim. Biophys. Acta, 119 (1966) 599-613.

11 T. C. Johnson, Cell-free protein synthesis by mouse brain during early development. J. Neurochem., 15 (1968) 1189-1194.

12 T. C. Johnson and G. Bely tschko, Alteration in microsomal protein sythesis during early development of mouse brain. Proc. Natl. Acad. Sci. U.S.A., 62 (1969) 844-851.

13 R. Ekstrom, D. S. H. Liu and A. Richardson, Changes in brain protein synthesis during the life span of male Fischer rats. Gerontology, 26 (1980) 121-128.

14 C. B. Breuer and J. R. Florini, Amino acid incorporation into protein by cell-free systems from rat skeletal muscle. IV. Effects of animal age, androgens, and anabolic agents on activity of muscle ribosomes. Biochemistry, 4 (1965) 1544-1550.

15 U. Srivastava, Polyribosome concentration of mouse skeletal muscle as a function of age. Arch. Biochem. Biophys., 130 (1959) 129-139.

$16 \mathrm{G}$. W. Britton and F. G. Sherman, Altered regulation of protein synthesis during aging as determined by in vitro ribosomal assays. Exp. Gerontol., 10 (1975) 67-77.

17 D. S. H. Liu, R. Ekstrom, J. W. Spicer and A. Richardson, Age-related changes in protein, RNA and DNA content and protein synthesis in rat testes. Exp. Gerontol., 13 (1978) 197-205.

18 W. I. P. Mainwaring, The effect of age on protein synthesis in mouse liver. Biochem. J., 113 (1969) $869-878$.

19 J. P. Hrachovec, Age changes in amino acid incorporation by rat liver microsomes. Gerontologia, 15 (1969) $52-63$.

$20 \mathrm{~J}$. C. Chen, P. Ove and A. I. Lansing, In vitro synthesis of microsomal protein and albumin in young and old rats. Biochim. Biophys. Acta, 312 (1973) 598-607.

21 D. E. Buetow and P. S. Gandhi, Decreased protein synthesis by microsomes isolated from senescent rat liver. Exp. Gerontol., 8 (1973) 243-249.

22 R. Comolli, Polyamine effects on ${ }^{14} \mathrm{C}$-leucine transfer to microsomal protein in rat liver cell free system during aging. Exp. Gerontol., 8 (1973) 307-313.

23 R. Comolli, Deficiency in accessory protein of native $40 \mathrm{~S}$ ribosomal subunits in the liver of aging rats. Exp. Gerontol., 10 (1975) 31-36.

24 R. Comolli, C. Delpiano and A. C. Shubert, Dependency on the source of supernatant factors for optimal ${ }^{14} \mathrm{C}$-poly phenylalanine synthesis by high salt treated liver ribosomal subunits in rats of different ages. Exp. Gerontol., 11 (1976) 5-10.

25 D. I. Kurtz, The effect of ageing on in vitro fidelity of translation in mouse liver. Biochim. Biophys. Acta, 407 (1975) 479-484.

26 D. I. Kurtz, A decrease in the number of active mouse liver ribosomes during aging. Exp. Gerontol., 13 (1978) 397-402.

27 D. K. Layman, G. A. Ricca and A. Richardson; The effect of age on protein synthesis and ribosome aggregation to messenger RNA in rat liver. Arch. Biochem. Biophys., 173 (1976) $246-254$.

$28 \mathrm{~J}$. T. Du, T. A. Beyer and C. A. Lang, Protein biosynthesis in aging mouse tissues. Exp. Gerontol., 12 (1977) 181-191.

$29 \mathrm{~K}$. Moldave, J. Harris, W. Sabo and I. Sadnik, Protein synthesis and aging: studies with cell-free mammalian systems. Fed. Proc., 38 (1979) 1979-1983.

30 P. Ove, M. Obenrader and A. Lansing, Synthesis and degradation of liver proteins in young and old rats. Biochim. Biophys. Acta, 277 (1972) 211-221.

31 C. F. A. Van Bezooijen, T. Grell and D. L. Knook, The effect of age on protein synthesis by isolated liver parenchy mal cells. Mech. Ageing Dev., 6 (1977) 293-304.

$32 \mathrm{M}$. Schramm, Amylase secretion in rat parotid slices by apparent activation of endogenous catecholamine. Biochim. Biophys. Acta, 165 (1968) 546-549.

33 A. Amsterdam, I. Ohad and M. Schramm, Dynamic changes in the ultrastructure of the acinar cell of the rat parotid gland during the secretory cycle. J. Cell Biol., 41 (1969) 753-773.

$34 \mathrm{~J}$. H. Lillie and S. S. Han, Secretory protein synthesis in the stimulated rat parotid gland. J. Cell Biol., 59 (1973) 708-721. 
35 A. Amsterdam, M. Schramm, I. Ohad, Y. Salomon and Z. Selinger, Concomitant synthesis of membrane protein and exportable protein of the secretory granule in rat parotid gland. $J$. Cell Biol., 50 (1971) 187-200.

36 G. Keleti and W. H. Lederer, Handbook of Micromethods for the Biological Sciences, van Nostrand Reinhold, New York, 1974, pp. 139-142.

37 O. H. Lowry, N. J. Rosebrough, A. L. Farr and R. J. Randall, Protein measurement with Folin phenol reagent. J. Biol. Chem., 193 (1951) 265-269.

38 A. Fenner, R. Traut, D. Mason and J. William-Cotfelt, Quantification of Coomassie blue stained proteins in polyacrylamide gels based on analysis of eluted dye. Anal. Biochem., 63 (1975) 595 602.

39 J. D. Castle, J. D. Jamieson and G. E. Palade, Radioautographic analysis of the secretory process in the parotid acinar cell of the rabbit. J. Cell Biol., 53 (197.2) 290-311.

40 S. K. Kim, D. W. Calkins and P. A. Weinhold, Secretion of $\alpha$-amylase from parotid lobules of young and old rats. Submitted for publication.

$41 \mathrm{H}$. Ito, B. J. Baum and G. S. Roth, $\beta$-Adrenergic regulation of rat parotid gland exocrine protein secretion during aging. Mech. Ageing Dev., 15 (1981) 177-188.

42 R. J. Grand and P. R. Gross, Independent stimulation of secretion and protein synthesis in rat parotid gland. J. Biol. Chem., 244 (1969) 5608-5615.

43 L. M. Sreebny, D. A. Johnson and M. R. Robinovitch, Functional regulation of protein synthesis in the rat parotid gland. J. Biol. Chem., 246 (1971) 3879-3884.

44 M. G. Rosenfeld, I. B. Abrass and B. Chang, Hormonal stimulation of $\alpha$-amylase synthesis in porcine pancreatic minces. Endocrinology, 99 (1976) 611-618.

45 M. A. McPherson and C. N. Hales, Control of amylase biosynthesis and release in the parotid gland of the rat. Biochem. J., 176 (1978) 855-863.

46 G. E. Palade, Intracellular aspects of the process of protein synthesis. Science, 189 (1975) 347358.

47 C. M. Redman, Biosynthesis of serum proteins and ferritin by free and attached ribosomes of rat liver. J. Biol. Chem., 244 (1969) 4308-4315.

48 M. Takagi, T. Tanaka and K. Ogata, Functional difference in protein synthesis between free and bound polysomes of rat liver. Biochim. Biophys. Acta, 217 (1970) 148-158.

49 P. Vassalli, B. Lisowska-Bernetein, M. E. Lamm and B. Benacerraf, Studies on cell free synthesis of rat immunoglobulins. II. Synthesis of immunoglobulin and of antibody to the dinitrophenol hapten. Proc. Natl. Acad. Sci. U.S.A., 58 (1967) 2422 2429.

50 P. Gaye, L. Houdebine, G. Petrissant and R. Denamur, Protein synthesis in mammary gland. Acta Endocrinol. Suppl., 180 (1973) $426-447$. 